Revista Iberoamericana, Vol. LXXXI, Núm. 251, Abril-Junio 2015, 465-482

\title{
TESTIMONIO Y (GEN)ÉTICA POSMEMORIA EN LOS RUBIOS DE ALBERTINA CARRI (2003)
}

\author{
POR \\ GUILLERMINA WALAS \\ Investigadora independiente
}

Si la naturaleza del testimonio se define por esa imposibilidad de desligar en la narración subjetiva y a la vez mediada por la puesta en relato, la ficción (como injerencia de lo imaginativo) de la verdad (aquello que se jura o promete revelar desde la perspectiva del testigo), tal aspecto controvertidamente dual se exacerba en el intento de construir el texto testimonial, o un documental en el registro fílmico, desde lo que se ha dado en llamar "posmemoria", es decir desde la posición de quienes no vivieron directa o activamente la historia sobre la cual testimonian más que de "segunda mano" o desde el margen, al heredar ciertas versiones así como las consecuencias de dicha historia y de las decisiones de quienes eran adultos entonces. En el contexto que nos ocupa, la representación fílmica de la historia en Latinoamérica y, en este trabajo, Argentina en particular, el filme Los rubios (2003) de Albertina Carri se percibe como paradigmático por la crítica precisamente por poner en relieve de una manera a la vez analítica y lúdica, seria pero completamente desacartonada, los problemas éticos tanto como estéticos de la representación histórica, desde la memoria y la búsqueda identitaria, sobre todo desde el punto de vista de la generación que hereda las marcas presentes de esa historia reciente sin haber sido activamente partícipe de la misma.

En Los rubios, dado el carácter semi-privado de lo que se busca descubrir, reconstruir y narrar (quiénes eran sus padres desaparecidos y cómo se relaciona esto con quién es ella, Albertina Carri, autora/directora y personaje protagónico del hoy tanto como del ayer en su situación como "hija de"), lo documental no refiere sólo a la existencia o no de testimonios y pruebas, sino a la transferencia de experiencia hecha memoria y de señas de identidad de una generación a otra, lo que en la película se transforma en una búsqueda ambigua, donde prima la ausencia y la falla o insuficiencia de los relatos documentales y de primera mano, pero al mismo tiempo también lo que esa ausencia ha generado: la insurgencia imaginativa para llenar los vacíos, con sus efectos positivos (la creación artística), tanto como negativos (la mentira como tergiversación de los hechos, registro equívoco de los sucesos o incluso difamación). En tal sentido, este filme es un testimonio de la imposibilidad de llegar a las claves que permitirían racionalizar 
y articular el pasado en historia comprensible de otra manera que no sea el camino creativo. Lo que sí se llega a entender en la búsqueda representada en Los rubios, es que el pasado está sujeto a un ineludible proceso de ficcionalización al ser re-significado en el ejercicio de memoria, tanto desde lo individual como desde lo colectivo. Este trabajo se propone entonces explorar cómo en el caso de Los rubios se manifiesta y cuestiona no ya la ambivalencia traumática de la memoria, sino incluso la ausencia de soportes que sostengan un relato de manera unilateralmente documental por lo cual todo puede ser puesto en duda y se convierte en material permeable a la ficción o, más aún, donde la ficción ya se ha asentado irremediablemente.

Por otra parte, planteamos que, a pesar de haber sido tomado como paradigmático, el filme mismo problematiza la idea de "posmemoria", ${ }^{1}$ lo que si bien afecta primordialmente al relato identitario-testimonial y subjetivo que se ofrece, se proyecta también a un planteo ético sobre la transmisión de la traumática memoria argentina, específicamente de los setenta, a las futuras generaciones, y sus relatos resultantes, sea que los sujetos hayan estado o no ligados por vínculo de sangre a aquellos que participaron en dicha etapa. $¿$ Cómo reconstruir y representar una historia en base a fragmentos testimoniales o de memoria autobiográfica cuando las claves de la misma parecen no sobrevivir más que en secciones incongruentes? ¿Cómo elaborar una narrativa coherente de la memoria cuando sólo reina la ausencia? Si la memoria no existe ni se substancia hasta articularse en narrativa $\mathrm{y}$, simultáneamente, la narrativa resultante se funda en imágenes, retazos subjetivos del pasado que son actualizados y proyectados como memoria, se hace difícil si no imposible pensar en representar narrativamente ese pasado que se ha vivido "desde el margen" en una infancia muy temprana, y luego, en la ausencia del relato y memoria directa de los protagonistas-testigos más cercanos, los padres.

Sin embargo, igualmente hay nombres, hay perceptibles lazos y herencias, incluso cuando el filme simule negarlas, aparentando a primera vista darle la espalda a las "influencias". ${ }^{2}$ Hay, sobre todo, espacios que necesitan ser dotados de significado,

1 A pesar de que ha sido usado sistemáticamente para abordar el filme desde la crítica (de lo cual nuestro trabajo también peca dado el título elegido), consideramos que el término "posmemoria" es debatible en su aplicabilidad sin cuestionamiento a Los rubios y a otros filmes de esta generación como si se tratara de un molde en el que este trabajo auto-referencial de Carri encaja perfectamente dentro del contexto argentino. Hay que aclarar aquí que por un lado, no es todo heredado en Carri ya que, como se verá, la experiencia le compete de primera mano en varios aspectos. Luego, "el molde" falla en la ausencia aquí de un relato de sobrevivientes en aquello que no se experimentó. Esto se abordará más adelante en el presente artículo.

2 Ana Amado, entre otros críticos, interpreta la película en relación al duelo y afirma que hay una negación o un corte con lo familiar que lleva a caminar a futuro "sin influencias". Esto se sostendría sobre todo por la escena del final según Amado (185-193). La presente aproximación, si bien coincide con la de esta crítica en varios puntos, difiere en éste al considerar que se trataría de una simulación más con la que se juega, otra puesta en escena o "pose" que, como se verá, tiene más que ver con un guiño sobre asumir la ficcionalidad del pasado sobre la que se construye la identidad que con la negación de las influencias. $\mathrm{Si}$

Revista Iberoamericana, Vol. LXXXI, Núm. 251, Abril-Junio 2015, 465-482 
retomados como pistas en una pesquisa que aunque se adivina nunca será totalmente completada, puede conducir a un esclarecimiento y a un estado de sanación para quienes la emprenden, narrando desde ese hiato de la ausencia. Para ello, la respuesta parecería estar en desmenuzar o desgranar los elementos existentes: documentos, anécdotas, relatos individuales dados a manera de testimonios, visiones contrapuestas y contradictorias de los hechos y cada porción, sin importar lo vaga que sea, de memoria propia y ajena para después rearmar con los fragmentos dispersos una trama que ponga de manifiesto, que exponga, las ambigüedades intrínsecas a todo intento testimonial (Sanders 5), así como la ineludible injerencia de componentes ficcionales/imaginativos.

Tal vez a raíz de los mencionados cuestionamientos que se postulan en el filme mismo, Los rubios propone una visión del pasado que podría caracterizarse como deconstruccionista en la narración fílmica, dando lugar a una estética revolucionaria o vanguardista ya desde los aspectos formales, pero que no se limita a ello. Como tal, incluso desde su proceso de factura que es puesto en escena y también incorporado a la narrativa, la película se ha interpretado como de una particular irreverencia, específicamente, hacia las luchas de la anterior generación, pero también como el ejemplo exacto sobre las representaciones de la posmemoria. En efecto, siguiendo todos coincidentemente las primeras teorizaciones de Marianne Hirsch en torno a dicho concepto, así como las reflexiones de Andreas Huyssen sobre la memoria en general y su incidencia en el presente, a excepción de Ana Amado, las aproximaciones crítico-ensayística al filme que hemos consultado (Sarlo, Nouzeilles, Quílez Esteve, Lazzara, entre otros), con sus diferencias, lo interpretan como narrativa de la posmemoria. Todos notan, asimismo, el posicionamiento cuestionador, desestructurante e incluso impertinente (Sarlo y Kohan) que plantea la película frente a los aspectos más trágicos de los años setenta en Argentina, debido a la ausencia, falla o inconexión con la memoria de la generación anterior. En este sentido, se puede ver, a pesar de usar los mismos marcos de análisis y terminología, las diferente posiciones dadas en la recepción. Por una parte, el análisis de Gabriela Nouzeilles, uno de los primeros ensayos académicos específicos publicado sobre el filme, es concluyente al señalar con signo positivo que Los rubios es una forma de intervención y que puede interpretarse en términos del pedido que intelectuales como Nicolás Casullo y Nelly Richard han efectuado sobre la necesidad de una mirada y pensamiento más crítico sobre el pasado y la memoria traumática de los sesenta y setenta (266).

En su combinación de lo trágico con lo lúdico, efectivamente, coincidimos con Nouzeilles en que la propuesta de Carri hace tambalear varios presupuestos de la audiencia (por ejemplo, la idea de que los hijos siguen los lineamientos políticos o incluso

se piensa la película como gesto político, incluso por negación, la influencia es no sólo aparente (en todos los sentidos del término) sino clave para entenderla.

Revista Iberoamericana, Vol. LXXXI, Núm. 251, Abril-Junio 2015, 465-482 ISSN 0034-9631 (Impreso)

ISSN 2154-4794 (Electrónico) 
asumen el carácter de némesis, vengadores de sus padres sin cuestionamiento alguno del accionar de éstos), mientras que a la vez confirma otros aspectos como el sinsentido del autoritarismo desaparecedor que marcó a fuego su historia e identidad particular, pero también la de todo el país, algo que filmes más recientes como $M$ (2007) de Nicolás Prividera en lo que hace al género documental-testimonial, o Infancia clandestina (2012) de Benjamín Ávila, en un encuadre ficcional y hollywoodense, marcan a su vez de otras maneras. En su artículo de 2005, Nouzeilles nota el movimiento pendular de la película entre rechazar y re-inscribirse, ya sea en las líneas del documental histórico, o por el contrario, del otro lado del péndulo, en las de la puesta en escena o en el performance (lo que lleva precisamente a que una parte de la recepción lo interprete como irreverente). Agregaríamos que tal movimiento también se produce en lo que hace a la dicotomía memoria-olvido, pero sobre todo a la actitud de crear y dar testimonio a la vez que se niega o se muestra el fracaso de dicho testimonio. ${ }^{3}$

En contraste respecto de varios puntos con el análisis anterior, también en una publicación de 2005, Beatriz Sarlo "rescata" el filme -tal vez para "hundirlo" con más fuerza en su juicio crítico-en una sección de Tiempo pasado como ejemplo de lo opuesto a lo indicado en la lectura previamente mencionada: una mirada superficial, desligada de la política (como si el desentenderse de la política no fuera acaso una postura política en sí misma) y sobre todo, narcisista al negar la identidad de quienes testimonian en el filme y reafirmarse como una película en torno al ego de la directora, girando de diferentes maneras sobre el nombre y persona de Albertina Carri. Sarlo concluye: "El filme de Carri es un ejemplo casi demasiado pleno de la fuerte subjetividad de la posmemoria [...]" (153). Pero, si "posmemoria", también según Sarlo, es simplemente "[...] lo que viene después de la memoria de quienes vivieron los hechos [...]" (128), el problema aquí es que Carri sí vivió parte de los hechos, aunque no hay casi memoria que se articule en relato dada su edad. En segundo lugar, la mediación de la que habla Sarlo se hace más compleja y fragmentada por el hecho de que sólo quedan relatos muy parciales de terceros, a diferencia de lo que sucede en los casos de posmemoria que analizan Hirsch y Young, críticos a los que sigue Sarlo para su aproximación al tema. Además, si bien es innegable que Sarlo está en lo cierto al acentuar la visión de clase y pertenencia que atraviesa y media la narrativa fílmica, sería simplificar el creer que esto solamente se pone en acto en el desenfado de la trama, en el juego con lo imaginativo o por lo que se releva desde el título mismo. Por el contrario, el filme tal vez propone desde lo personal un

3 El tema del "fracaso" y de la "pérdida" es retomado también en la aproximación de Michael Lazzara a este y otro filme del 2003, La televisión y yo de Andrés DiTella. Remito a dicho artículo para más sobre este punto. Sobre la dicotomía memoria-olvido y la pendularidad en general de Los rubios, cabría decir que es el motivo principal por el cual la película sigue dando qué hablar. No sólo nos referimos a este presente ensayo, sino, por ejemplo, al artículo periodístico de Martín Kohan "Las heridas abiertas de la memoria" donde revisita en 2013 su percepción de Los rubios como un pedido de olvido. 
desafío a los estereotipos racistas, entre otros, tan impregnados en la sociedad argentina, para plantear desde allí toda una serie de falsos presupuestos sobre el pasado, personal y colectivo. Aunque parezca banal o anecdótico si los Carri y sus hijas eran o no rubios, a través de dicho punto de disidencia entre lo que dicen y recuerdan los testigos del barrio versus las fotos, la memoria y la propia autopercepción identitaria de la directora, el filme se convierte casi en un ensayo sociológico e historiográfico (¿qué elige recordar una sociedad? ¿qué pasa si lo que se recuerda es una mentira montada sobre prejuicios racistas desde diferentes bandos?). Es interesante que en la simplificación del tema, por parte de Sarlo, no se vea esto, tal vez porque también opera en su "lectura" la misma visión de clase, grupo social y sobre todo generacional de la intelectual argentina, en tanto la película desde el ángulo de las ambigüedades interpretativas se mostraría en un primer plano como detractor de la intelectualidad de la generación anterior (la de Sarlo, la de los propios padres de Carri).

En efecto, desde el filme hay una crítica aparente hacia esa generación y al grupo específico de intelectuales-activistas que se creyó con la capacidad y el derecho incontestable de representar al pueblo, a las masas trabajadoras, lo que puede observarse en una posible interpretación de la lectura que el personaje de Albertina (Analía Couceyro) hace de uno de los epígrafes a Isidro Velázquez (el ensayo sociológico escrito por su padre, Roberto Carri), en los primeros cinco minutos del filme, cuando la actriz todavía no se ha presentado ni postulado la auto-ficción, lo que es clave para interpretarlo en sus dobleces. ${ }^{4}$ Hay que tener en cuenta que lo que se cita mediante la lectura en el filme, sin embargo, no son palabras del padre de Albertina, sino un pasaje de Historia de las agitaciones campesinas andaluzas, de Juan Díaz del Moral, que Roberto Carri usa de detonador para el argumento de su ensayo, junto con otros dos epígrafes, uno del Martín Fierro y otro de un chamamé en honor al "bandido" Velázquez muerto en 1967, sólo un año antes de la publicación del ensayo. También habría que observar la intertextualidad de Isidro Velázquez en diferentes niveles, los paralelismos y las paradojas que se tejen en y entre ambos. Explica Roberto Carri en el Prólogo sobre Velázquez: "Lo real (...) no es siempre lo que Velázquez y Gauna [...] hicieron durante un largo período de sus andanzas en el monte, sino aquello que la inmensa mayoría entendía que Velázquez significaba para ellos" (14). Agrega, además que su objetivo es el estudio de formas de protesta que aparentan no tener contenido político manifiesto, pero "que indudablemente lo tienen" (15). De esto se desprende que, de similar manera, Albertina Carri muestra

4 Sobre la auto-ficción en Los rubios remito al ensayo de Laia Quílez Esteve. Respecto de la crítica generacional, sobre lo que se hablará más adelante, es interesante aquí advertir que Beatriz Sarlo introduce su lectura del filme con un análisis en tercera persona, aunque notablemente subjetivo, sobre el heroísmo de su propia generación que según ella, confrontó con justicia los errores de la anterior ante el "trauma" del 17 de octubre del 45 (144), postulando así una genealogía de enfrentamientos generacionales que el filme continuaría.

Revista Iberoamericana, Vol. LXXXI, Núm. 251, Abril-Junio 2015, 465-482 
que lo que prevalece es lo que se entendió que eran sus padres ("agitadores rubios", extranjeros con su máquina de escribir, para los entrevistados del barrio, por ejemplo), lo cual abre un manojo de posibilidades que no coinciden con "lo real" en su percepción de "hija", partícipe de la historia. La narrativa fílmica desmenuza inteligentemente este problema, y lo hace a su vez con una rebeldía que es leída como apolítica, o más bien, como renegada de la fuerte posición política que sostuvieron sus padres (Sarlo, Kohan, e incluso Amado sostienen tal "lectura"), cuando en cambio, como bien señalaba ya el mismo Roberto Carri, aún lo que en su contenido no es manifiestamente político, indudablemente lo es. Estos son solamente dos ejemplos de cómo las estrategias de deconstrucción y afirmación por la negación mueven el discurso fílmico hacia una multiplicidad de sentidos cuestionadores.

Otra manera de entender el deconstruccionismo como táctica narrativa en Los rubios así como los movimientos ambiguos y contestatarios del filme estaría en pensar que ésta es una estrategia que celebra, no las apariencias como indicó Martín Kohan, también en una lectura muy condenatoria y obviamente marcada por la brecha generacional, sino la gran amplitud de posibilidades interpretativas del recuerdo o incluso las tergiversaciones del mismo. ${ }^{5}$ De nuevo, si no es a base de parcialidades, ¿de qué otra manera reconstruir y representar esta historia, incomprensible y dolorosa, dada la cercanía de los hechos y así y todo la fragilidad de la memoria -la propia y la de otros, individual y colectiva- cuando, como se ha dicho más arriba, parecen no sobrevivir más que borrosas imágenes de los protagonistas? Hayden White, en un ensayo sobre el posmodernismo y las "ansiedades" que éste genera específicamente en los historiadores, reflexiona sobre dos aspectos que podríamos conectar con el filme en cuestión. Primero, White destaca la dificultad de "aprehender" o registrar el pasaje de un momento o período histórico a otro (305), lo que se relaciona con las transiciones y, en otra escala que aplicaríamos más específicamente a Los rubios, se entendería como el dilema de representar el pasaje de la vivencia (acontecer histórico) al relato (también histórico). Carri y su historia se encuentran precisamente en esa bisagra, puesto que ella ha vivido los hechos, pero no como para contar o contener el relato en calidad de testigo y, por otra parte, las fuentes que detenta y su manejo resulta frágil, o para algunos como Sarlo o Kohan, cuestionables por varios motivos, pero principalmente por la cercanía con lo personal y subjetivo, más aquella de los hechos mismos, vividos pero no de forma activa o "participativa". Es interesante notar en este sentido que Kohan,

\footnotetext{
Para este comentario he seguido lo que señala Jonathan Culler acerca del deconstruccionismo derridiano, notando que el mismo ha sido muchas veces entendido desde la crítica norteamericana como una ataque a la literatura cuando en el contexto de su obra se trata más bien de un paradigma celebratorio (909). Respecto de Kohan, me refiero aquí a su primera aproximación al filme en "La apariencia celebrada". Cabe aclarar que, aunque más cercanos a la generación de Carri que de Sarlo, Martín Kohan podría verse como "hermano mayor" que toma partido por sus padres intelectuales.
}

Revista Iberoamericana, Vol. LXXXI, Núm. 251, Abril-Junio 2015, 465-482 ISSN 0034-9631 (Impreso) 
en "Las heridas abiertas de la memoria", destaca positivamente, en contraste con Los rubios, filmes como El Predio (2010) de Jonathan Perel. De la misma generación y similar postura ideológica que Carri, Perel podría considerarse igualmente posmoderno y deconstruccionista, pero desde una estética minimalista, aparentemente ascética de toda subjetividad al establecer una ficción de objetividad dada por las tomas fijas y el merodeo “espontáneo" de la lente por la ex ESMA, que se hallaba en el proceso de ser convertida en "Espacio para la Memoria y para la Defensa de los Derechos Humanos" durante el momento de factura del filme. ${ }^{6}$ Es evidente que aunque no exista una "performance" aparente ante la cámara como sucede en Los rubios, no por ello el discurso de Perel es necesariamente más objetivo (ni lo intenta ser): similar a lo que sucede en la escritura, siempre hay alguien que posiciona, dirige, enfoca, acerca o aleja la lente, marcando un camino de lectura o de cuestionamiento.

En segundo lugar y en este sentido, ya refiriendo a una consideración estético-epocal de Los rubios, afirma White que el posmodernismo trata la idea misma de conocimiento histórico como algo construido, "made up" (306), lo que en ciertos contextos equivale a decir "ficticio". Precisamente, creemos que Los rubios pone sobre el tapete dicha cuestión. Cuando los documentos aparecen diseminados fragmentaria y contradictoriamente, sumándose a que el periodo histórico es relativamente reciente, los testigos-protagonistas se hallan ausentes y no se puede, quiere, ni debe hablar por ellos; cuando no existe un discurso coherente que llene los vacíos, la memoria como conocimiento de los hechos se vuelve equivalente a ficción en su carácter primariamente imaginativo. ¿Qué queda entonces para que las generaciones futuras construyan como "posmemoria" y lo que es más, como historia ya sea identitaria, colectiva o ambas? Este es un planteo latente, no sólo en Los rubios sino en muchas de las producciones tanto fílmicas como literarias de la generación de Albertina Carri.

Desde otro ángulo teórico, al hablar sobre el testimonio como narración de hechos presenciados de primera mano basándose en el conocido escrito de Maurice Blanchot, "L'instant de ma mort", Jacques Derrida nos dice que nada es más absurdo para el sentido común que hablar de una experiencia no experimentada (47), cuando por ejemplo se busca dar testimonio de algo catastrófico como la propia muerte. Tal absurdo, que resultaría o bien en una mentira o en la construcción de un relato de ficción, es lo que parece querer demostrar la película de Carri, pero no ya en términos de experiencia personal sino de la memoria misma, la propia (muy pobre tratándose de una niña de 3 años al acontecer los hechos) y aquella testimonial que se recoge de terceros para indagar en lo que desintegró su núcleo familiar y en la identidad de los padres tanto como de sí misma. También explica Derrida otro aspecto clave: para permanecer como tal un

6 Para más sobre la ESMA (Escuela de Mecánica de la Armada, que sirviera de centro clandestino de tortura durante la dictadura militar) y esta conversión remito a mi artículo "Alternativas testimoniales..." (Walas).

Revista Iberoamericana, Vol. LXXXI, Núm. 251, Abril-Junio 2015, 465-482 ISSN 0034-9631 (Impreso)

ISSN 2154-4794 (Electrónico) 
testimonio debe mantenerse bajo el acoso permanente de ambos la verdad y el perjurio, la ficción y lo documentado, la ley y lo que está fuera de ella, entre otros vaivenes, porque si deja de "demorarse" en este límite, si se decide por uno de éstos, por ejemplo convirtiéndose en archivo, pasa a perder su función de atestiguar activamente (30). Por su parte, al referirse al testimonio respecto de la experiencia puntual de Auschwitz, Giorgio Agamben reflexiona sobre esa misma paradoja del testimonio que se despliega en una imposibilidad narrativa, en tanto su valor reside y se basa precisamente en lo que le falta (34). Los que sobrevivieron no pueden dar cuenta de la experiencia de los que no están y tampoco siquiera de su posición de sobrevivientes por el trauma de aquello refrendado de primera mano. Menos posibilidades de superar esto quedarían para las generaciones herederas del mismo. Sin embargo, refiriéndose críticamente al análisis que Shoshana Felman y Dori Laub hacen del filme Shoah (1985) de Claude Lanzmann, contrario a pensar en su estetización, Agamben afirma que el testimonio encuentra la posibilidad de la expresión artística (en un poema o en una melodía, por ejemplo), lo cual no resuelve su paradoja sino que la articula (36).

Así, el filme de Carri, como otros textos de su generación que cuestionan las versiones o "documentación" del pasado, sitúa al espectador/receptor ante la incongruencia e imposibilidad de documentar lo indocumentable, más allá de lo que sí es certero: de un lado la ausencia o, peor, la "desaparición", pero del otro, la influencia, lo que ha quedado de manera hereditaria y lo que se hace presente de forma ineludible. ${ }^{7}$ La película de Carri en una posible interpretación de su final propondría que son los hijos, o las nuevas generaciones, el testimonio mismo, al mantener activa la función de seguir representando (o intentando hacerlo) aquello irrepresentable y en ese proceso, continuar moviéndose en el terreno estrecho entre imaginario y verdad sobre lo acontecido. En este contexto,

\footnotetext{
Digo "textos" con el fin de incluir diferentes medios de representación. En lo literario, por ejemplo, $L a$ casa de los conejos (2010 en español) de Laura Alcoba o desde el marco ficcional, la novela de Leopoldo Brizuela , Una misma noche (2012) entrarían en este conjunto. Me detendré en ello más adelante. Por otro lado, en lo que atañe a la filmografía de esta generación, la misma es abundante y presenta una variedad de estéticas desde las que se tiende a concluir dejando en claro la imposibilidad de acercarse tanto a la identidad de y a la identificación con los padres como a una visión comprensiva de los hechos o de la memoria. Los casos de Papá Iván (2000) de María Inés Roqué y M (2007) de Nicolás Prividera en cuanto a un enfoque documental pero personal, El Predio (2010), Los Murales (2009) o Tabula Rasa (2013) en el caso de la perspectiva documental aparentemente impersonal, como se ha mencionado, y luego Cordero de Dios (2008) de Lucía Cedrón en lo ficcional serían ejemplos claros de la diversidad de enfoques. También lo sería como versión fílmica de una petite mémoire o narrativa ficcionalizada de una memoria de infancia, Infancia clandestina (2012) de Benjamín Ávila. Además, es diferente la perspectiva que se observa en aquellas producciones de factura colectiva, con testimonios variados de la generación de "hijos"(incluso de la agrupación HIJOS), pero con fuerte intervención autoral, de producción o dirección de sujetos de la generación de los "padres"/ "abuelos": Televisión x la identidad, de Colom-Telefé con Abuelas de Plaza de Mayo, Ni el flaco perdón de Dios de Gelman y La Madrid, o Victoria de Jaime, entre otros, serían ejemplos de esta otra perspectiva.
}

Revista Iberoamericana, Vol. LXXXI, Núm. 251, Abril-Junio 2015, 465-482 ISSN 0034-9631 (Impreso) ISSN 2154-4794 (Electrónico) 
la identidad como "hija de" se transforma en una evidencia difícil de afrontar para el colectivo tanto como para sí misma, y en una ficción en tanto constructo que reúne diferentes percepciones, donde todo se relativiza bajo lentes diversas (clase, posición política, generación, lazos afectivos, etcétera). Mantenerse allí, en esa zona polémica, en lo parcial de la memoria y en el cuestionamiento ético y estético de las versiones que se quieren unívocas, es la clave testimonial que se propone en Los rubios.

Este juego dual que, como menciona Nouzeilles, es evidenterespecto de la inscripción o no en el género documental-testimonial, se ve además en varios planos del filme, siendo el más explícito el desdoblamiento de la figura de Albertina Carri, su estar y no estar, su estar multiplicada por dos en ciertas tomas: la narrativa fragmentada se plantea por una parte como puramente subjetiva, dada desde la primera persona autobiográfica en cuanto sabemos que se trata de una auto-referencia real y concreta (el nombre de la directora es uno de los primeros títulos que se le presentan a la audiencia). Luego, aun si nunca antes escuchamos hablar de los Carri, parte de los títulos también nos informan sobre quiénes eran, aprendemos que la directora es la hija menor del matrimonio y podemos comprender la importancia de esta historia que en primera instancia parecería privada, pero no lo es dada la fuerte incidencia en ella de los hechos nacionales (más precisamente, del accionar del terrorismo de Estado) a nivel colectivo como país. A la vez, sin embargo, existe un distanciamiento de lo privado y subjetivo mediante la objetivación de la figura de Albertina, en el desplazamiento y duplicación de lo subjetivo y privado a través del explícito recurso de la auto-ficción: la actriz Analía Couceyro se presenta ante la cámara. La sustitución de la verdadera Carri, sobre todo en los segmentos más autobiográficos, la performatividad de ese otro, permite una distancia del yo, un efecto de extrañamiento que conduce a la observación y al análisis así como por momentos dota a la película de un cierto humor desestructurante de la tragedia con la muestra de una faceta lúdica al exponerse el relato ante la cámara: por ejemplo, en la escena en que la protagonista va a hacerse el examen de ADN a Antropología Forense, en medio de la solemnidad del trámite, mostrado sin sonido en su mayor parte, tanto la doble de Albertina (la actriz) como la Albertina real (la directora) dejan sus muestras, pero el funcionario asume lo ficcional por real cuando casi se olvida de tomar la muestra de la Carri real después de haberlo hecho con la actriz, lo que produce cierta confusión, pero también alguna hilaridad en la escena frente a cámara y posiblemente en su percepción. De tal manera, este episodio, adrede sin editar (o editado para precisamente mostrar), hace evidente que el proceso de desdoblamiento se proyecta a su vez en la auto-referencialidad que adopta en lo formal el filme mismo y en su proceso de producción: por un lado, asistimos al documental sobre la búsqueda de Albertina, personaje, ficcionalización y alter-ego; $y$, a la vez, estamos ante el documental sobre su factura que es también una búsqueda, donde aparece sí la "real" Albertina Carri, persona, dirigiendo ese filme sobre sí misma y la imposibilidad de hallar lo buscado más que a través de un proceso creativo, donde la imaginación es una herramienta clave y necesaria para la memoria.

Revista Iberoamericana, Vol. LXXXI, Núm. 251, Abril-Junio 2015, 465-482 ISSN 0034-9631 (Impreso) ISSN 2154-4794 (Electrónico) 
Además, a medida que avanza la narrativa, se afirma lo que sugeríamos: Los rubios en su búsqueda y compilación de fragmentos de la memoria no coincide con lo definido y analizado por Marianne Hirsch como "narrativas de posmemoria" (22) o al menos no en forma tan "plena" como lo ha indicado la crítica (específicamente, Sarlo 153). Pero vayamos por partes. En primer lugar, Carri no sólo "heredó" la historia traumática de sus padres, sino que la vivió de primera mano, aunque pasivamente $\mathrm{y}$, por haber sido muy niña en ese entonces, no le es posible recordar más que en forma borrosa. En el filme se enfatiza en varias secciones que existe ese recuerdo, vago, pero todavía de primera mano. Además, a diferencia de los ejemplos de Hirsch, que son en su mayoría de hijos o nietos de sobrevivientes, Carri sufrió directamente la historia al quedar huérfana como consecuencia de los hechos. Luego, entendemos que si bien el filme trata en parte de la herencia o legado identitario de la generación que vivió los acontecimientos históricos como adultos, el trauma, en este caso, afecta a la segunda generación también directamente y no "de segunda mano" puesto que la directora perdió a sus padres. A pesar de haber sido una niña, vivió, desde un margen, podría decirse, ese momento de violencia en que se los llevaron, según se muestra cuando la actriz, frente a la última casa que Albertina Carri habitó con sus padres, narra lo poco que la directora recuerda. Por supuesto, en el juego dual entre ficción e historia, dado que se trata de un performance de la actriz, el receptor no tiene certeza de si ésta es o no una memoria "real" o una puesta en escena creativa.

Queda claro, sin embargo que uno de los principales puntos de diferenciación con las narrativas analizadas por Mariane Hirsch es que no hay aquí memoria guiada por padres sobrevivientes y aquellos sobrevivientes que son entrevistados evidencian que no compartieron (y menos todavía pueden "dar cuenta de") la experiencia de los que no están. ${ }^{8}$ Los que estuvieron más cerca de tal experiencia, tienen actitudes como la de Paula L., quien no quiere presentarse como testigo frente a cámara, por lo cual su

8 Al decir que "no compartieron", no me refiero sólo al haber estado o no en situaciones semejantes o haber coincidido en eventos y actividades o en la posición política, sino me refiero a que hay otro aspecto que distancia las narrativas analizadas por Hirsch de aquellas de los hijos de quienes sufrieron persecución política y desaparición durante la dictadura argentina: es que mientras las primeras, sobre el Holocausto, resultan unánimemente condenatorias de los hechos y existe una división bastante nítida entre "víctima" y "victimario", esto no ocurre en el segundo caso, donde tal división se torna borrosa, incluso al recoger relatos de activistas políticos de la época que podrían haber estado militando en el mismo sector de los padres y que hoy en día tienen una mirada condenatoria. Los relatos-sobrevivientes presentan un abanico muy amplio de posturas sobre la "culpabilidad" o responsabilidad de las víctimas más allá de condenar sí en forma unánime las formas, tácticas y monstruosidades del Estado como aparato represor y desaparecedor; por ende, la narrativa posmemoria resultante difiere de la lógica que siguen aquellas estudiadas por Hirsch en cuanto a un cuestionamiento mayor de la generación que vivió los hechos, de los padres y de los relatos heredados. Se podría expandir mucho más sobre este tema, pero valga aquí esta mención que apunta a una más de las variables en las que se debería reflexionar al aplicarse el término.

Revista Iberoamericana, Vol. LXXXI, Núm. 251, Abril-Junio 2015, 465-482 
versión aparece mediada por el personaje de Carri que lo narra indirectamente ("Me contó $[\ldots]$ y me contó también [...]"). De ahí, el absurdo que por momentos el filme plantea al intentar explicar, racionalizar, narrar la ausencia o aquello de lo que nadie puede dar testimonio: la muerte propia tanto como la muerte del Otro.

Se podría decir, sin embargo, que la memoria en todo caso es literalmente un "post" en cuanto, según se explicita en el filme, empieza en ese "después" y en la ausencia: la llegada al campo ya sin los padres, habiendo perdido el contacto con ellos, según enuncia casi sobre el final la protagonista (Carri ficcionalizada) mientras parece estar ensamblando un collage fotográfico: "el campo es el lugar de la fantasía, o donde comienza mi memoria”. Así el lugar donde comienza la memoria es también donde principia paradójicamente el proceso creativo, la fantasía, la ficción, el juego: ambos procesos homologados documentan y sostienen la identidad.

En efecto, la narrativa se inicia con cuatro clips de material diverso que marcan el punto germinal en diferentes planos así como la complejidad del trauma identitario y de la memoria:

1) El principio del filme y de su producción: tras unos primeros títulos que anuncian al productor general, a la directora y a la actriz de la película, la cámara hace un paneo por el set de playmobils mientras que una camarógrafa o alguien del equipo técnico le pregunta a la directora ("Alber") si ese es el enfoque deseado.

2) Todavía con la visión de los playmobils, una voz en off de mujer habla posiblemente de un caballo, diciendo que es "mansito" y "re bueno" e invita a alguien a subirse; esta voz, que pasa a tener como locación o telón de fondo el campo, se vuelve identificable con la de la "Carri real" y la segunda voz que se escucha, con la de la actriz o "Carri personaje". En una lectura más atenta, en el contexto de la narración autobiográfica completa, la voz inicial representa tal vez la primera memoria de la llegada al campo, a la tía joven de Albertina-niña invitándola a subirse a un caballo; este es el punto inicial de la identidad post-padres, aparentemente ajena a lo urbano y a la situación política nacional, en "El campito", el campo de sus tíos que como bien nota Beatriz Sarlo, irónicamente resuena a "campo de concentración" durante el terrorismo de Estado (148). ${ }^{9}$

3) La ya mencionada lectura de Isidro Velázquez, el estudio sociológico de Roberto Carri, padre de la directora, marca también un inicio, en tanto la película busca indagar en quiénes eran sus padres y leer sus escritos es una forma de hacerlo, pero además señala una conexión con el padre, una influencia, como hemos visto, en ese rol de interrogar que el filme propone, casi como un ensayo sociológico.

4) El regreso al barrio, en busca de testimonios (o de memoria) donde la familia fue desintegrada por el secuestro de los padres. Esto indica el comienzo de la búsqueda

\footnotetext{
"El campito" es el nombre de guerra que le fue dado también a "Los Tordos", predio adyacente a Campo de Mayo (principal guarnición militar de Argentina) en la provincia de Buenos Aires, donde operó uno de los mayores centros clandestinos de detención ilegal durante la última dictadura militar.
}

Revista Iberoamericana, Vol. LXXXI, Núm. 251, Abril-Junio 2015, 465-482 ISSN 0034-9631 (Impreso) ISSN 2154-4794 (Electrónico) 
y del filme en todo sentido en tanto como espectadores descubriremos que es en las entrevistas a los vecinos que éste adquiere su nombre/título y es allí donde el documental como "memoria $=$ verdad irrefutable" se desplaza a lo ficcional como "memoria $=$ reconstrucción imaginativa".

En tal camino, la identidad como hija se debate entre sentimientos, representaciones e interpretaciones como "real" (verdadera, fidedigna) o "ficticia" (inventada, falsa o fingida): entre los dos parámetros, la identidad, sin duda, se crea y re-crea. En una escena posterior, después de que la actriz ya se ha presentado y se han hecho explícitos los códigos, el alter ego - personaje de la directora en la película (Analía Couceyro) escribe: "Exponer la memoria en su propio mecanismo. Al omitir, recuerda," mientras escucha en entrevistas grabadas los superficiales comentarios y recuerdos de familiares y amigos, quienes supuestamente conocieron de cerca a sus padres y quienes sí habrían compartido aunque parcialmente la experiencia. ${ }^{10}$ Se trata entonces de leer imaginativamente el vacío, la ausencia, la omisión para llegar a la memoria o a sus mecanismos. De nuevo, el juego paradójico y dual, el documental transformado en ficción o la ficción que termina por documentar(se).

En tal sentido, saltando al final de la película, éste, en definitiva, es revelador de los símbolos que hasta allí la narrativa fílmica ha desplegado en claves dispersas: a pesar de haberse negado y cuestionado a través del relato la característica de "rubios" de la familia, Carri y su grupo de trabajo, su familia "postiza" (como lo son las pelucas) en esta última escena, adopta ese rasgo mediante la ficción del disfraz: un hombre y cuatro mujeres, de las cuales Carri por su altura simula ser la menor (como lo es en realidad en su familia nuclear), caminan de espaldas hacia el horizonte campestre, en un amanecer soleado, hacia el futuro. Así, la pérdida familiar y la falta de memoria articulada en relato sobre su pasado hacen que lo imaginativo más que dialogar o confrontarse con la verdad, ya la haya reemplazado con esta familia "protética", puesto que funciona como "prótesis" de la faltante, amputada por los militares. Falso o verdadero, este despliegue se traslada también al trazado de otros lazos comunitarios, que a futuro son asumidos imaginativamente como familia, pero en términos de una relación fluida y flexible (Nouzeilles 266, 275). Este reemplazo final mediante el juego ficcional es uno más de los movimientos lúdicos, el broche último, que propone Carri en su deconstruccionismo para cuestionar las versiones dadas tanto como las veladas de la historia.

Como se sabe, el intento de documentar omisiones, de poner sobre el tapete las diversas interpretaciones del pasado, revelando las ficciones del recuerdo de manera transgresora y mofándose incluso de la tragedia real y propia de ser hija de desaparecidos por la dictadura, le valió al proyecto y a la película resultante la crítica y oposición de

10 Esta frase ("Exponer la memoria...”) sería de la autoría de Ricardo Forster según lo señalado en los títulos, al final del filme (Carri, Los rubios).

Revista Iberoamericana, Vol. LXXXI, Núm. 251, Abril-Junio 2015, 465-482 ISSN 0034-9631 (Impreso)

ISSN 2154-4794 (Electrónico) 
intelectuales de la generación de los padres de la directora, a la vez que se constituyó como base de su éxito y originalidad. Tal circunstancia se representa como una autoreflexión en la escena fílmica donde se lee y discute la carta del Instituto Nacional de Artes Audiovisuales. Los emisores de la carta manifiestan una actitud ambigua hacia el proyecto: por un lado, siguiendo tácticas que semejan las de political correctness norteamericanas, apoyan su realización, pero se muestran apáticos o incluso reticentes, en cuanto a las formas y procedimientos, tal vez porque se trata de un acercamiento posmoderno al relato, tanto subjetivo como histórico. En síntesis, la conclusión en torno de esta escena es que el desencuentro generacional es insoslayable tanto dentro del filme en la visión/representación cuestionadora de Carri y la carta del INCAA, como en la recepción, según notábamos en la mencionada crítica de Sarlo o de Kohan, a quien Sarlo cita para apoyarse (147) y otros intelectuales de la misma generación que Sarlo y otros críticos consagrados.

Obviamente el desacuerdo generacional en la lectura tanto como en la puesta en relato de los hechos no es algo exclusivo de Los rubios y es hasta incluso esperable que se produzca dicha “discusión”. Veamos qué pasa en otras producciones de planteo intergeneracional. En Cordero de Dios de Lucía Cedrón, por ejemplo, la ficción representa a madre e hija en una visión contrapuesta sobre el pasado y la imagen o rol del padre y abuelo en la historia, mostrando que la carga de culpa o, en oposición, la inocencia, es siempre relativa a lo que se conoce y al lugar subjetivo desde donde se viven los hechos. Por su parte, Infancia clandestina, una de las más recientes ficcionalizaciones cinematográficas de los años 70, también de raigambre en la historia personal de su director, Benjamín Ávila, presenta la incomprensión del narrador, aunque la perspectiva del niño púber y la focalización en su primer amor le quitan protagonismo y perspectiva al cuestionamiento histórico y hacia los padres. Otros casos a destacar de producciones recientes que muestran el desacuerdo generacional, aunque fuera de la cinematografía, serían Lengua Madre, de María Teresa Andruetto (que desde una ficción marcadamente autorreferencial, pero que invierte roles en la correspondencia entre ficción y realidad, se centra en la brecha generacional), Una misma noche de Leopoldo Brizuela y La casa de los conejos de Laura Alcoba, donde las memorias también fragmentadas de los años de infancia resurgen en ambos para ser leídas de manera crítica, ya sea en un marco ficcional o explícitamente autobiográfico. En cuanto al tema de la posmemoria y de la herencia de versiones sólo por vía del relato, no hay tal en el caso de Alcoba, ni en Brizuela, ni tampoco en los filmes de Ávila, Cedrón e incluso, menos todavía, en Carri: todos ellos, autores-creadores tanto como sus personajes o alter-egos ficcionales, experimentaron de primera mano la historia, aunque desde una posición pasiva dada su condición de niños, y no encuentran sujetos que, habiendo vivido la etapa como adultos, ofrezcan versiones confiables, o completas y coherentes. De ahí que haya un intento por volver al lugar de un recuerdo que, si incluso no se materializa como tal, por lo menos

Revista Iberoamericana, Vol. LXXXI, Núm. 251, Abril-Junio 2015, 465-482 ISSN 0034-9631 (Impreso)

ISSN 2154-4794 (Electrónico) 
se intuye: tanto en Los rubios de Carri como en Cordero de Dios, Una misma noche y La casa de los conejos, la textualidad se presenta en algún momento como un volver al lugar de una vivencia obtenida de primera mano en la niñez, algo borroso que ya desde la voz adulta se intenta articular en narración, fílmica o literaria, con el fin último de comprender, pero también de dar testimonio desde el lugar y rol jugado en la historia.

En definitiva, en este sentido, la posmemoria no es tan "post” o tan sólo y únicamente algo que llega "después", por vía de una herencia y de un relato en Los rubios. Esto puede verse, desde otro ángulo si se focaliza precisamente en lo relativo al regreso a los espacios más traumáticos para el sujeto en cuestión: por ejemplo, en la búsqueda de testimonios en el barrio donde se vivió por última vez con los padres, como familia, hay una diferencia respecto de lo que sucede en la visita a la sede de policía que sirvió de centro de detención de los padres, conocido solamente desde el relato de otros, puesto que en el primero se evidencia ante la cámara que hay un esfuerzo por encontrar vestigios de un recuerdo de primera mano de los hechos que no existiría si la memoria fuera nada más que vicaria o heredada. ${ }^{11}$ Por otra parte, la directora es "reconocida" por una de las vecinas, lo que la ubica como sujeto de la historia y con derecho a contarla de primera mano. Aunque existe igualmente una ambigüedad cuando la "verdadera" Carri dice "Yo no me acuerdo de nada", en la primera escena del barrio, también en otra toma su voz señala con certeza, que "Es ahí, en esa casa con rejas" afirmando un recuerdo de primera mano. Luego, su alter ego ficcional contará lo que recuerda frente a la casa. Pero todo es puesto en duda y se muestra como verdad tambaleante dado que el relato se articula frente a la cámara desde la actuación, siendo anunciado incluso en

${ }^{11}$ Respecto de este volver al lugar de los hechos, Hirsch ha escrito extensamente también sobre la posmemoria, basándose en el trabajo de campo con su esposo Leo Spitzer, posicionándose ambos en el lugar de la pos-memoria en tanto hijos de sobrevivientes. Aunque la definición más citada de Hirsch sobre ésta no hace mención de esto al caracterizarla como " [...] the experience of those who grow up dominated by narratives that preceeded their births, whose own belated stories are evacuated by the stories of the previous generation shaped by traumatic experiences that can be neither understood not recreated" (Family Frames 22), en sus artículos posteriores, en coautoría con Spitzer, se detiene más en dos aspectos: a) al viaje al lugar de los hechos traumáticos por parte de la generación que "heredó" la memoria pero no vivió los hechos, y b) la importancia del relato "guía" o que provee esa memoria. En estos ensayos se enfatiza entonces el rol clave de esos sujetos protagonistas directos del evento, de quienes se escuchó de primera mano la historia en la reconstrucción del relato de la pos-memoria. En "“There was Never a Camp Here'...", donde como Agamben, Felman y otros, se considera el paradigmático filme de Lanzmann como punto de partida para hablar de representación fílmica, documental/ testimonial del regreso al espacio traumático, tanto como en "'We Would Not Have Come Without You'...", ensayo de corte más autobiográfico, se subraya ya desde la cita del sobreviviente, la función de éste como guía y clave de la reconstrucción narrativa, algo que está ausente (padres) o marginal, parcial y fragmentado (amigos, vecinos, conocidos, familiares) en la/s narrativa/s que recibe Carri. Además, como lo nota Tina Wasserman, a diferencia de otras teorías similares, la de Hirsch conecta específicamente este concepto con la experiencia de los hijos de sobrevivientes (Wasserman 166). 
la preparación de esa toma como "ficción": no sabemos si es una memoria "real" o "ficcional" en el sentido de creada completamente para la película o simplemente puesta "en acto" de lo que existe como memoria de una vivencia real, de primera mano, aunque borrosa y por lo mismo, plagada de imaginación.

Por otro lado, en la visita a la seccional de policía donde funcionó el centro de detención ilegal conocido como el "Sheraton", donde los padres de la directora estuvieron secuestrados, aunque esto no se vivió de primera mano, la misma duda entre lo que se sabe o cree saber y lo que se escucha, ve y constata vuelve a aparecer. Sin embargo, en esta visita sí se trataría de posmemoria en cuanto lo que se sabe se ha obtenido por relatos de otros y no por vivencia directa. Así y todo, de nuevo, la vuelta al lugar de los hechos no está guiada directamente por los protagonistas y su relato, como sucede en los análisis de Hirsch, donde siempre existe una narración testimonial, de experiencia directa, que forja la versión del Otro, "post”" o hereditario. Según se explicita en el filme, además de lo asentado en el Nunca más, la única guía directa para Albertina Carri sería el testimonio de Paula L. Sin embargo, la narración de esta testigo también aparece mediada y en forma indirecta: más allá de no mostrarse ni hablar en cámara justificándose en un extraño paralelismo entre "testimoniar"y "delatar", según se explícita a través del relato indirecto de Couceyro/Carri, la supuesta Paula L. se niega a darle el diagrama que hizo del lugar y tampoco acompaña al grupo. Por lo cual, con esta otra ausencia, orfandad de testigos directos, las imágenes de la posmemoria se vuelven más tambaleantes, produciendo también para el espectador la fluctuación, la duda entre realidad y ficción, acentuada asimismo por los comentarios frente a cámara sobre posibles diferencias o inconsistencias entre lo asentado en los documentos/ testimonios sobre el lugar y lo que se ve y puede constatar desde el hoy. Volver a los lugares del relato o de un recuerdo vago, casi perdido construye otro testimonio, éste sí indudablemente de primera mano, donde vemos la tambaleante y frágil arquitectura de la historia.

En su ensayo "Constructing the Image of Postmemory", Tina Wasserman analiza dos producciones audiovisuales que podrían compararse con el filme en cuestión: Cooperation of Parts (1987) de Daniel Eisenberg sobre sus padres y el Holocausto, y History and Memory: For Akiko and Takashige (1991) de Rea Tajiri sobre los campos de concentración japoneses en Estados Unidos durante la Segunda Guerra Mundial. Estas narrativas, a diferencia de Los rubios, sí son completamente resultado de una "posmemoria", en tanto los artistas-directores no han estado en los lugares que investigan o exploran más que a partir de fotos y del relato de sus padres sobrevivientes hasta el momento de producción. A diferencia de Carri, insisto, estos realizadores no vivieron la situación traumática más que a través de un relato o memoria heredada y de la visita a esos lugares donde dicho trauma se ocasionó; tal relato en Los rubios está ausente -ha desaparecido con los padres- lo cual agudiza el trauma que se padece de primera mano en el caso de la directora argentina. A pesar de esta disimilitud que, como se ha dicho,

Revista Iberoamericana, Vol. LXXXI, Núm. 251, Abril-Junio 2015, 465-482 ISSN 0034-9631 (Impreso)

ISSN 2154-4794 (Electrónico) 
hace muy cuestionable la aplicación del término posmemoria como un molde crítico exacto a Los rubios, es evidente asimismo, por lo que observa Wasserman, que esas narrativas visuales comparten algo más que el carácter experimental al confrontar, desde lo personal la historia colectiva, "autorizada", para comprobar la necesidad ética de recuperar otras versiones, aún cuando el texto resultante sea polémico, incomprensible o parezca sesgado de ficciones y subjetivismo. Una de esas características compartidas es el proveer imágenes que estaban en el ámbito familiar y hacerlas públicas a través del filme. Hay una recuperación visual que hace a la memoria tanto individual como colectiva, ya sea que se reflote lo que fue conocido por experiencia propia (el barrio en Carri) o por relatos heredados o de terceros (el centro de detención clandestina).

Recapitulando: aunque es innegable que en algunos aspectos Los rubios comparte características y se muestra como una narrativa (o intento) de narrar explorando la historia desde la posmemoria, es, a su vez y sobre todo, un documental que paradójicamente da cuenta de la dificultad de "documentar", puesto que lo que sí se "documenta" es una experiencia de primera mano acerca de la fragilidad de la memoria, de su carácter acomodaticio y fluctuante más allá de los deseos de quienes la posean, la busquen, la deseen o, incluso, la hereden, sobre todo si los hechos y personas a rememorar tienen una carga traumática tal como la que deja en un niño la desaparición de sus padres. No se trata de una celebración de las apariencias (Kohan), sino en todo caso de una exposición de las diferencias entre versiones y visiones de los hechos así como de sus actores, lo que asimismo implica una puesta en escena para revelar la mayor y más dolorosa verdad que les toca sobre todo afrontar a los hijos de las víctimas del terrorismo de Estado: sobre la imposibilidad de paradójicamente, dilucidar la verdad.

Finalmente, como lo indica el texto de Marta Dillón para un trabajo más reciente de Carri, un cortometraje relacionado a la censura en los sesenta y setentas efectuado en el marco de un ciclo conmemorativo del bicentenario, "Acumular imágenes es una forma de la memoria. Volverlas disponibles es necesario para desbrozar la huella por la que seguir andando" (Restos). Siguiendo esto, no habría, como lo entendió la crítica perteneciente a la generación de los padres, una burla de la memoria (lo que implicaría sin duda una falta ética), sino, por el contrario, una voluntad de "desbrozar huellas", de cuestionar las trazas existentes del pasado, lo que necesita también hacerse para revelar el presente y sus absurdos. Así, como lo indica el tema musical que cierra la narrativa y esos "rubios" que vemos de espalda, la familia figurada que representa por sustitución sin ser la real, pero "como si", la historia en las diferentes versiones que se tejen sobre el pasado, proyecta simbólicamente la parcialidad de imágenes, muchas veces producto de estereotipos arraigados aunque ficticios como "la familia rubia", que sigue caminando por esa huella de verdad dada incluso en el barroso, confuso presente, a futuro, con ineludible influencia. 


\section{BIBLIOGRAFÍA}

Agamben, Giorgio. Remnants of Auschwitz. The Witness and the Archive. Daniel HellerRoazen, trad. Nueva York: Zone Books, 2002.

Alcoba, Laura. La casa de los conejos. Leopoldo Brizuela, trad. Buenos Aires: Edhasa, 2008.

Amado, Ana. La imagen justa. Cine argentino y politica (1980-2007). Buenos Aires: Colihue, 2009.

Andruetto, María Teresa. Lengua Madre. Buenos Aires: Mondadori, 2010.

Ávila, Benjamín, dir. Infancia clandestina. Habitación 1520 Producciones, 2012.

Brizuela, Leopoldo. Una misma noche. Buenos Aires: Alfaguara, 2012.

Carri, Albertina, dir. Los rubios. Barry Ellsworth, 2003.

"Restos". 25 miradas-200 minutos. Act. Esteban Lamothe, Voz Analía Couceyro, Texto Marta Dillón. Secretaría de Cultura de la Nación, Argentina, 2010.

Carri, Roberto. Isidro Velázquez. Formas prerrevolucionarias de la violencia. Buenos Aires: Sudestada, 1968.

Cedrón, Lucía, dir. Cordero de Dios. Le Filmes d'Ici, Lita Stantic y Goa Filmes, Prods., 2008.

Culler, Jonathan. "Introduction: Critical Paradigms.” PMLA 125/4 (2010): 905-915.

Derrida, Jacques. Demeure. Fiction and Testimony. Elizabeth Rottenberg, trad. Stanford: Stanford UP, 2000.

Donda, Victoria. Mi nombre es Victoria. Buenos Aires: Sudamericana, 2009.

Forster, Ricardo. "De batallas y olvidos: el retorno de los setenta". Políticas de la memoria. Tensiones en la palabra y la imagen. Sandra Lorenzano y Ralph Buchenhorst, eds. Buenos Aires: Gorla, 2007. 63-94.

Hirsch, Marianne. Family Frames: Photography, Narrative and Postmemory. Cambridge: Harvard UP, 1997.

Hirsch, Marianne y Leo Spitzer. "There Was Never a Camp Here. Searching for Vapniarka.” Locating Memory. Photographic Acts. Annette Kuhn y Kirsten Emiko McAllister, eds. Nueva York-Oxford: Berghabn Books, 2002. 135-54.

"“We Would Not Have Come Without You': Generations of Nostalgia." American Imago 59/3 (2002): 253-76.

Jaime, Adrián, dir. Victoria. Cecilia Merchán-INCAA, Prods., 2008.

Kohan, Martín. "La apariencia celebrada”. Punto de Vista 78 (2004): 26-30.

"Las heridas abiertas de la memoria". Clarín. Revista N. 22 marzo 2013. <http:// www.revistaenie.clarin.com/ideas/heridas-abiertas-memoria_0_887911210.html>. Junio 2015.

Lazzara, Michael. "Filming Loss. (Post-)Memory, Subjectivity and the Performance of Failure in Recent Argentine Documentary Films." Latin American Perspectives 36/5 (2009): 147-57.

Revista Iberoamericana, Vol. LXXXI, Núm. 251, Abril-Junio 2015, 465-482 ISSN 0034-9631 (Impreso)

ISSN 2154-4794 (Electrónico) 
Nouzeilles, Gabriela. "Postmemory Cinema and the Future of the Past in Albertina Carri's Los rubios." Journal of Latin American Studies 14/3 (2005): 263-278.

Painceira, Lalo. Dar la vida. La resistencia en Calle 30. La Plata: De la Campana, 2006. Perel, Jonathan, dir. El predio. FMCAC, 2010.

Prividera, Nicolás, dir. M. Nicolás Prividera, Guión, Vanessa Ragone y Pablo Ratto, Prods., 2007.

Quílez Esteve, Laia. “Autobiografía y ficción en el documental contemporáneo argentino.

Los rubios de Albertina Carri: un caso paradigmático". El cine argentino de hoy: entre el arte y la política. Viviana Rangel, ed. Buenos Aires: Biblos, 2007. 71-85.

Ramos Padilla, Juan Martín, Chicha. La fundadora de abuelas de Plaza de Mayo.

Buenos Aires: Editorial Dunken, 2006.

Sanders, Mark. Ambiguities of Witnessing. Law and Literature in the Time of a Truth Commission. Stanford: Stanford UP, 2007.

Sarlo, Beatriz. Tiempo pasado. Cultura de la memoria y giro subjetivo. Una discusión. Buenos Aires: Siglo veintiuno, 2005.

Walas, Guillermina. "Alternativas testimoniales: gestión cultural y memoria en Argentina”. Revista Iberoamericana LXXVII/236-237 (July-Dec. 2011): 885-917. Wasserman, Tina. "Constructing the Image of Postmemory." The Image and The Witness.

Trauma, Memory and Visual Culture. Frances Guerin y Roger Hallas, eds. LondonNueva York: Wallflower Press, 2007. 159-172.

White, Hayden. The Fiction of Narrative. Essays on History, Literature, and Theory. Baltimore: The Johns Hopkins UP, 2010. 